\title{
Experimental Nets for a Protection System against the Vectors of Xylella fastidiosa Wells et al.
}

\author{
Sergio Castellano ${ }^{1, *(\mathbb{D}}$, Antonella Di Palma ${ }^{1}$, Giacinto S. Germinara ${ }^{1}$, Marco Lippolis ${ }^{2}$, \\ Giuseppe Starace $^{3}(\mathbb{D})$ and Giacomo Scarascia-Mugnozza ${ }^{4}$ \\ 1 Department of the Sciences of Agriculture, Food and Environment (DiSAFE), University of Foggia, \\ Via Napoli 25, 71100 Foggia, Italy; antonella.dipalma@unifg.it (A.D.P.); giacinto.germinara@unifg.it (G.S.G.) \\ 2 Sachim Srl, Via Mastricale 7, 70017 Putignano, Italy; marco.lippolis@sachim.it \\ 3 Department of Engineering for Innovation, University of Salento, Via per Arnesano, 73100 Lecce, Italy; \\ giuseppe.starace@unisalento.it \\ 4 Department of Agricultural and Environmental Science (DiSAAT), University of Bari Aldo Moro, \\ Via Orabona 4, 70125 Bari, Italy; giacomo.scarasciamugnozza@uniba.it \\ * Correspondence: sergio.castellano@unifg.it; Tel.: +39-0881-589-406
}

Received: 18 December 2018; Accepted: 1 February 2019; Published: 5 February 2019

\begin{abstract}
The effectiveness of experimental nets in preventing the access of adult meadow spittlebug Philaenus spumarius L., the main vector of Xylella fastidiosa Wells et al. subspecies pauca, sequence type (ST) 53, in olive tree nurseries and orchards was evaluated. To optimize the net design, mesh size, kind of fabric, thread typology, and radiometric properties, six nets with different mesh sizes and kinds of fabric were evaluated in laboratory and in field experiments. Laboratory bioassays evaluating the capability of adult spittlebugs to pass through nets with different mesh sizes $(1.2,1.8$, $2.4 \mathrm{~mm}$ ) showed that all nets with a mesh size equal to or lower than $2.4 \mathrm{~mm}$ prevented insect crossing. These results were confirmed in field conditions using an experimental net box apparatus. Further laboratory tests showed a positive correlation between porosity and radiometric properties of the nets. Three prototypes of thermally stabilized flat woven nets made of circular cross-sectional yarns, knitted net with strips, and knitted nets made of yarns were tested after the evaluation of their potential usability in terms of porosity stability. The knitted net features were found to be the most suitable. The net transmissivity of the total and direct component of solar radiation in the photosynthetically active radiation and the infrared ranges increased with the net porosity. A prism-shaped wooden frame with a triangular base covered with the knitted net with a $2.4 \mathrm{~mm}$ mesh confirmed the insect's capability of reaching considerable heights, up to $2.85 \mathrm{~m}$. Hence, based on our results, the monowire knitted net with a $2.4 \mathrm{~mm}$ mesh can be used in open field nursery and olive orchards to prevent the access of $P$. spumarius adults and to shield the openings of greenhouse nurseries.
\end{abstract}

Keywords: insect-proof net; integrated pest management; nursery; olive tree

\section{Introduction}

In the Apulia region, olive tree cultivation covers almost 370,000 ha, with a yearly economic value of production around $492 \mathrm{M} €[1]$, representing 53.3\% of the overall farmland in the southern area of the region [2]. Moreover, centennial olive trees, which are very common in southern Apulia, are an important attraction for tourists as part of the cultural, traditional, and historical heritage of the region [3].

In 2010, olive trees on the west coast of Salento Peninsula (Apulia region, Italy) began to decline and die with a condition of unknown aetiology called "olive quick decline syndrome" [4]. Saponari et al. [5] demonstrated that olive trees with leaf scorch symptoms (i.e., branches with basal 
and apical pale green leaves, later expressing different degrees of scorching starting at the leaf tips, partial defoliation, and death of shoots and branches) were positive for Xylella fastidiosa Wells et al. subspecies pauca, sequence type (ST) 53 (Xanthomonadales, Xanthomonadaceae) [6]. This study was the first widespread detection of this bacterium in Europe, and a quarantine around the infected area was imposed [7]. Unfortunately, quarantine was not able to limit the diffusion of the bacterium and, by the end of 2013, the affected area had grown to almost the entire Salento Peninsula. Philaenus spumarius L. (Hemiptera, Aphrophoridae) is the most common spittlebug species in olive tree orchards in the Salento Peninsula, and it has been reported as the main vector of X. fastidiosa $[5,8]$.

The nursery industry is an important part of the agricultural sector in Apulia, and the production of "Xylella-free" plants is therefore of strategic importance for local and foreign markets [9]. In fact, $X$. fastidiosa affects not only olive trees but also more than 30 different commercial crops and wild species [10]. In this context, the development of preventive control measures to avoid bacterium transmission by known and potential insect vectors is crucial, as is the selection of tolerant or resistant olive tree varieties [11].

In recent years, the use of insect-proof nets in protected cultivation has increased, mainly to reduce the use of pesticides [12-14]. Due to the small size of some insect pests (i.e., thrips, aphids), very fine mesh nets are required $[13,15]$. Consequently, the use of such nets significantly reduces greenhouse ventilation $[16,17]$ and modifies the exchange of radiation and mass between crops and the atmosphere $[12,18]$. In some cases, microclimate modifications induced by insect nets can improve yield in addition to reducing pesticides $[19,20]$.

The mesh of the net should be as wide as possible in order to minimize the effects on environmental parameters (temperature, air humidity, solar radiation transmission, permeability to air) and structural issues (visual impact, wind loads, size of supporting structures) [13]. The size of the mesh also influences the distribution of flying insects near windbreak fences [21].

$X$. fastidiosa transmission by P. spumarius is mainly attributed to the adults, which are able to fly; juveniles do not fly and live on herbaceous plants protected in the spittle they produce [22]. Moreover, the low chance that young instars might transmit the bacterium is further reduced by the loss of infectivity with the moult [8]. Therefore, in order to successfully protect olive trees, the mesh of the net should prevent the passing through of P. spumarius adults [5,23].

In the present study, laboratory and semi-field behavioral tests were carried out in order to evaluate the capability of experimental nets with different mesh sizes and textures to prevent the passing through of P. spumarius adults. Based on the laboratory and semi-field tests, the net with the wider mesh size and the most suitable fabric for the purpose was identified. Moreover, the main radiometric properties of the experimental nets were determined. Finally, a demonstration trial was undertaken to preliminarily evaluate in the field the vertical distribution of P. spumarius adults in the first four meters above the ground level.

\section{Materials and Methods}

Three experimental nets with different mesh sizes $\left(\mathrm{d}_{1}=1.2 \mathrm{~mm}, \mathrm{~d}_{2}=1.8 \mathrm{~mm}, \mathrm{~d}_{3}=2.4 \mathrm{~mm}\right)$, selected on the basis of adult $P$. spumarius body length (male, $5.3-6.0 \mathrm{~mm}$; female $5.4-6.9 \mathrm{~mm}$ ) and head width $(2.5 \mathrm{~mm})$ [24], were tested. In this study, the mesh size was defined as the maximum dimension of a line segment inscribed in the hole of the net.

Three prototypes of different textures were chosen (Figure 1): (1) a thermally stabilized flat woven net (F) with transparent yarns; (2) knitted net made of white strips and transparent yarns (KS); (3) knitted net only made of transparent yarns (KW). Monofilaments had a circular cross section and were made of high-density polyethylene (HDPE); strips were made of low-density polyethylene (LDPE). Due to manufacturing limitations, six nets were tested: $F-d_{1}$ flat woven with mesh size $1.2 \mathrm{~mm}$, F- $\mathrm{d}_{2}$ flat woven with mesh size $1.8 \mathrm{~mm}, \mathrm{~F}-\mathrm{d}_{3}$ flat woven with mesh size $2.4 \mathrm{~mm}, \mathrm{KS}-\mathrm{d}_{1}$ knitted net made of strips and wires with mesh size $1.2 \mathrm{~mm}, \mathrm{KS}-\mathrm{d}_{2}$ knitted net made of strips and wires with mesh size $1.8 \mathrm{~mm}$, and $\mathrm{KW}-\mathrm{d}_{3}$ knitted net only made of wires with mesh size $2.4 \mathrm{~mm}$. 


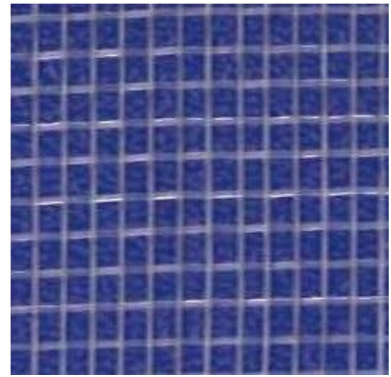

(a)

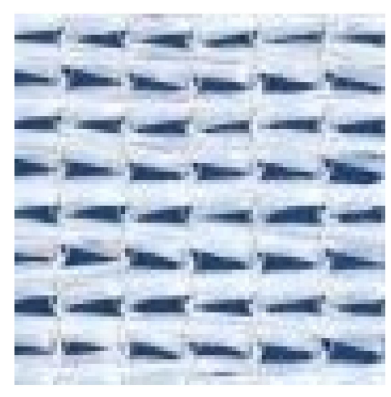

(b)

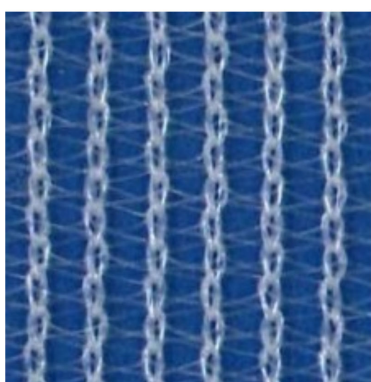

(c)

Figure 1. Pictures of the nets tested: (a) F- $\mathrm{d}_{3}$, flat woven with mesh size $2.4 \mathrm{~mm}$; (b) KS- $\mathrm{d}_{2}$, knitted net made of strips and wires with mesh size $1.8 \mathrm{~mm}$; (c) $\mathrm{KW}-\mathrm{d}_{3}$, knitted net made only of wires with mesh size $2.4 \mathrm{~mm}$.

Experimental nets were manufactured by SACHIM SRL (Putignano, Bari, Italy).

\subsection{Laboratory Behavioral Bioassays}

Nymphs of P. spumarius were collected from spontaneous herbaceous vegetation (mainly, the genera Sonchus, Foeniculum, Medicago, Vicia) near Foggia (Apulia, Italy) and transferred to shoots of Vicia faba L. seedlings in plexiglas cages and maintained at $23 \pm 2{ }^{\circ} \mathrm{C}, 70 \pm 5 \%$ relative humidity (r.h.), and 14:10 light:dark (L:D) photoperiod. Emerged adults were daily transferred to new cages and provided with fresh $V$. faba seedlings. Adults that were 1-2 days old were used for the experiments.

In order to test the capability of adult spittlebugs to move through different experimental nets, laboratory bioassays were carried out. The device used was made of two glass cylindrical jars separated by the net to be tested. Ten insects were released in the upper jar ( $\varnothing 25 \mathrm{~cm} \times 20 \mathrm{~cm}$ ), whereas two-week-old faba bean plants $(n=5)$ were positioned in the lower jar $(\varnothing 25 \mathrm{~cm} \times 20 \mathrm{~cm})$ with the apical shoots at least $3 \mathrm{~cm}$ below the net to avoid insect feeding. The upper jar was closed with nonwoven fabric to prevent insect escape. Insects were kept without food to motivate them to reach the shoots underneath. The number of insects crossing through the net was measured at 24-h intervals until all insects were dead. For each net, six replicates were performed.

\subsection{Semi-Field Behavioral Tests}

The experimental nets were further evaluated in semi-field tests using an experimental apparatus (net box). A young plant of olive tree was put inside a steel frame $(40 \times 40 \mathrm{~cm}$ base, $80 \mathrm{~cm}$ height) covered with one of the experimental nets. The frame with the plant was placed in a larger one $(80 \times 80 \mathrm{~cm}$ base, $120 \mathrm{~cm}$ height) covered with an anti-aphid net, where 25 P. spumarius adults were released (Figure 2). Because no water or food was supplied to the insects, they were expected to be strongly motivated to pass through the net and reach the olive tree in the inner box. For each type of net, four replicates were performed. Tests were carried out during April and May 2017 at the experimental station of the University of Bari (Valenzano, BA). The presence of insects in the inner box with the plant was checked every $24 \mathrm{~h}$ until all insects were dead. 


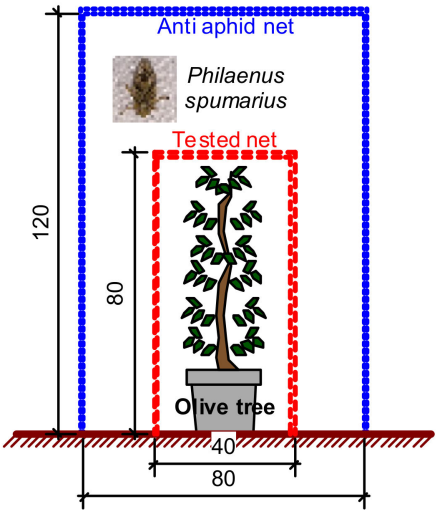

(a)

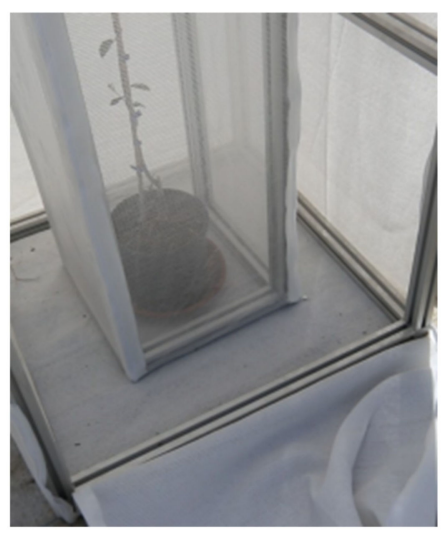

(b)

Figure 2. Net box used for field test: (a) construction scheme and (b) picture. Units are in $\mathrm{cm}$; the image of the insect in the construction scheme is not to scale.

\subsection{Radiometric Tests}

Radiometric tests on the nets were carried out at the University of Bari by means of spectrophotometer (1760X, Perkin-Elmer Instruments, Norwalk, CT, USA). The spectral transmissivity $\tau(\lambda)$ was evaluated over different wavelength bands: solar and near-infrared radiation wavelength range (290-2500 $\mathrm{nm})$, photosynthetically active radiation (PAR) range (400-700 nm), and far-infrared radiation (long-wave infrared, LWIR) range $(>2500 \mathrm{~nm}$ ). Spectral direct perpendicular transmissivity was measured in the solar and near-infrared radiation range (290-2500 $\mathrm{nm}$ in steps of $10 \mathrm{~nm}$ ) by a double beam with a direct perpendicular incidence UV-VIS-NIR spectrophotometer (Lambda 950, Perkin Elmer Instruments, Waltham, MA, USA). Spectral transmissivity in the LWIR range, between 2500 and $25000 \mathrm{~nm}$, was measured by a FT-IR spectrophotometer using radiation with a direct perpendicular incidence. The transmissivity coefficients in the LWIR range were calculated as average values of the spectral transmissivity in the wavelength range from 7500 to $12500 \mathrm{~nm}$. For each experimental net, five samples were tested; the average values and standard deviation of radiometric properties were calculated.

The porosity $(\Phi=S e / S t)$ is defined as the ratio between the surface of empties $(S e)$ and the area of the net $(S t)$. It is one of the main parameters involved in the radiometric properties of the net $[25,26]$. Porosity plays an important role in the evaluation of the air permeability of the net and, consequently, of wind loads on the structure [27]. The porosity of tested nets was measured by means of image analysis [25].

\subsection{Field Demonstration Trial}

To preliminarily evaluate the vertical distribution of $P$. spumarius adults in the first four meters above the ground level, a prism-shaped wooden frame ( $4.0 \mathrm{~m}$ high) with a triangular base $(1.0 \mathrm{~m} \times 1.0 \mathrm{~m} \times 1.0 \mathrm{~m})$ was covered with a KW-knitted net $(2.4 \mathrm{~mm}$ mesh) (Figure 3). On the three sides of the frame, 12 yellow sticky traps $(20 \times 20 \mathrm{~cm})$ (Novapher, Milan, Italy) were placed [28] at different heights $(40,85,185,285,390 \mathrm{~cm})$. The triangular shape of the net-covered frame was designed in order to evaluate the incidence of adult spittlebugs on the net for any direction. The frame was installed in an olive tree orchard located at the experimental station of the University of Bari $\left(41^{\circ} 01^{\prime} 16.48^{\prime \prime} \mathrm{N}, 16^{\circ} 54^{\prime} 18.39^{\prime \prime}\right.$ E, Elev. $\left.120 \mathrm{~m}\right)$ from July 3 to October 31, 2017. Traps were replaced four times (31 July, 31 August, 30 September, 31 October), and spittlebugs stuck on the traps were identified and counted. 


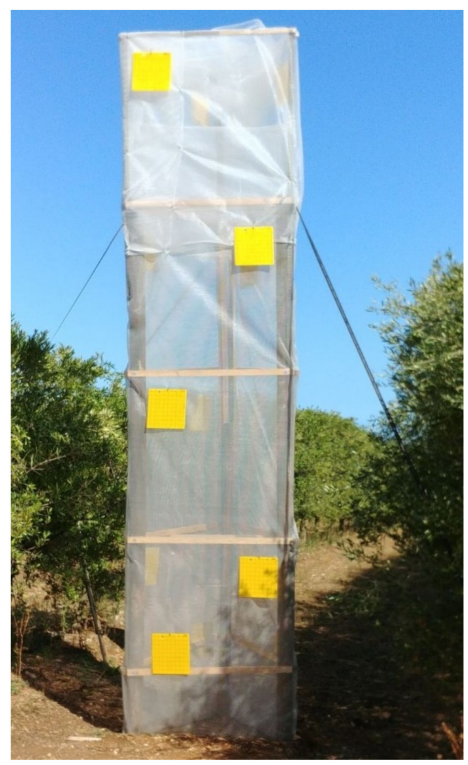

Figure 3. Wooden frame covered with the net and yellow sticky traps at different heights.

\section{Results}

In laboratory and in semi-field experiments, none of the P. spumarius adults was able to pass through the experimental nets with different textures and a mesh size range of $1.2-2.4 \mathrm{~mm}$. Therefore, a net with mesh size equal to or lower than $2.4 \mathrm{~mm}$ can successfully prevent the arrival of meadow spittlebugs on plants and, hence, the possible transmission of X. fastidiosa.

The analyzed nets showed potentially different stability in terms of hole shapes and mesh dimension. The prototype of flat woven nets could be subject to damages of some thermal connections. Knitted net with strips showed trip twisting and a very low porosity. Knitted nets with wires very hardly showed lack of stability or twisting with consequent variation of porosity (Table 1).

Table 1. Construction characteristics of nets tested. Flat woven net (F), knitted nets made of strips and yarns (KS), and only of yarns (KW); $\mathrm{d}$ is the maximum linear dimension of the mesh $(\mathrm{mm})$.

\begin{tabular}{ccccc}
\hline Tested Net & $\mathbf{d}(\mathbf{m m})$ & Porosity $\mathbf{( \% )}$ & Warp Diameter $(\mathbf{m m})$ & Weft Diameter $(\mathbf{m m})$ \\
\hline F-d1 & 1.2 & 58.11 & 0.28 & 0.28 \\
F-d2 & 1.8 & 64.62 & 0.28 & 0.28 \\
F-d3 & 2.4 & 71.60 & 0.28 & 0.28 \\
KS-d1 & 1.2 & 6.27 & 0.26 & Strips $(90 \mu \mathrm{m}$ thickness $)$ \\
KS-d2 & 1.8 & 18.00 & 0.26 & Strips $(60 \mu$ m thickness $)$ \\
KW-d3 & 2.4 & 42.96 & 0.23 & 0.23 \\
\hline
\end{tabular}

Laboratory tests (Table 2) confirmed the correlation between porosity and radiometric properties of the nets tested. The transmissivity of total $(\tau-T o t)$ and direct component of solar radiation in PAR range ( $\tau$-Dir) increased with the porosity as well as the transmissivity of the net in the IR range. As a result, the greenhouse effect was minimized with a higher porosity of the net (Figure 4). Haze and transmissivity of the diffuse component of the solar radiation in PAR ( $\tau$-Dif) showed, as expected, an opposite behavior, i.e., both decreased as the porosity increased (Figure 4).

In field demonstration trial, all yellow sticky traps captured eight and nineteens adults of P. spumarius and Neophilaenus campestris (Fallen), respectively. For the latter species, the role of vector in the transmission of $X$. fastidiosa was recently demonstrated (unpublished data). Vertical distribution of insect vector captures was almost uniform in the first $285 \mathrm{~cm}$ above ground level, while no insect catches were found from 285 to $390 \mathrm{~cm}$. Considering the low number of insects captured and their uniform distribution in the first $285 \mathrm{~cm}$ above the ground level, statistical analysis was not performed. 
Table 2. Radiometric properties of the nets tested (\%). $\tau$-Tot total transmissivity in photosynthetically active radiation (PAR) $(400-700 \mathrm{~nm}), \tau$-Dir direct transmissivity in PAR range, $\tau$-Dif diffuse transmissivity in PAR range, Haze in PAR range, $\tau$-LWIR transmissivity in far infrared (7500-12500 nm). Data are expressed as measured average values \pm values of standard deviation.

\begin{tabular}{cccccc}
\hline Tested Net & $\boldsymbol{\tau}$-Tot & $\boldsymbol{\tau}$-Dir & $\boldsymbol{\tau}$-Dif & Haze & $\boldsymbol{\tau}$-LWIR \\
\hline F-d1 & $0.967 \pm 0.010$ & $0.585 \pm 0.006$ & $0.383 \pm 0.004$ & $0.396 \pm 0.005$ & $0.553 \pm 0.011$ \\
F-d2 & $0.975 \pm 0.013$ & $0.650 \pm 0.010$ & $0.325 \pm 0.004$ & $0.333 \pm 0.010$ & $0.617 \pm 0.011$ \\
F-d3 & $0.979 \pm 0.012$ & $0.703 \pm 0.009$ & $0.276 \pm 0.005$ & $0.282 \pm 0.012$ & $0.690 \pm 0.013$ \\
KS-d1 & $0.511 \pm 0.021$ & $0.047 \pm 0.003$ & $0.464 \pm 0.019$ & $0.908 \pm 0.016$ & $0.348 \pm 0.008$ \\
KS-d2 & $0.545 \pm 0.023$ & $0.229 \pm 0.010$ & $0.316 \pm 0.012$ & $0.579 \pm 0.011$ & $0.398 \pm 0.016$ \\
KW-d3 & $0.948 \pm 0.016$ & $0.531 \pm 0.009$ & $0.417 \pm 0.007$ & $0.440 \pm 0.009$ & $0.488 \pm 0.012$ \\
\hline
\end{tabular}

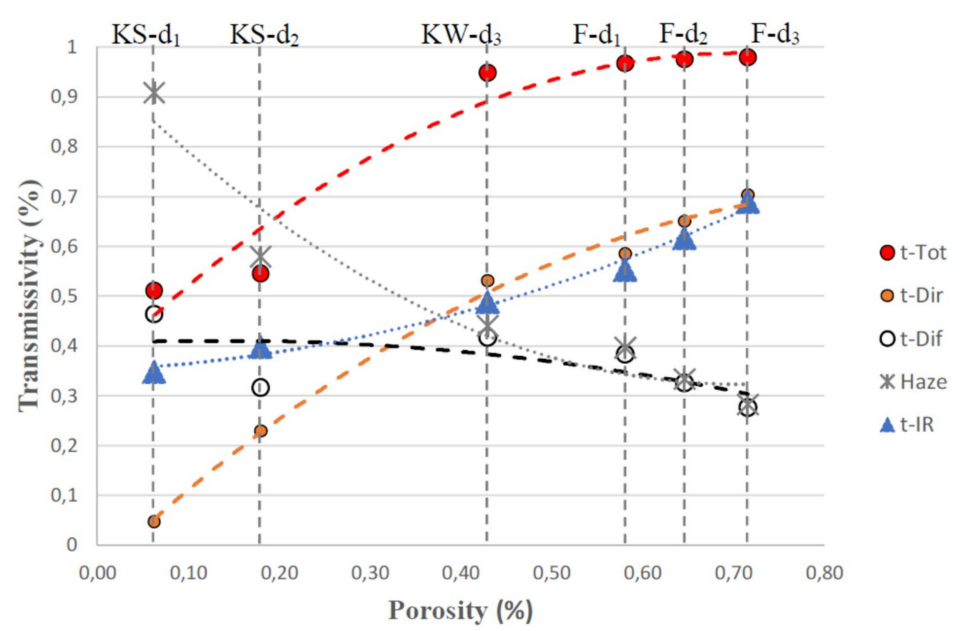

Figure 4. Correlation between average values of radiometric properties of the nets tested and $\Phi$, porosity. Dashed lines represent polynomial correlation curves of measured parameters.

\section{Discussion}

P. spumarius adults, unable to reach the vegetation, died within 24 and $48 \mathrm{~h}$ after the experiments started in semi-field and laboratory conditions, respectively. This is consistent with the observations made by Weaver and King [29], who reported that succulent foliage suits the adults the best as it offers a plentiful supply of moisture.

Laboratory and semi-field experiments showed that a net with the mesh size equal to or lower than $2.4 \mathrm{~mm}$ can successfully prevent the arrival of meadow spittlebugs on plants and, hence, the possible transmission of $X$. fastidiosa. Concerning the stability of the mesh size, the prototype of flat woven net showed some damages to the yarn thermal connections. For this reason, the prototype of flat woven did not fit our purpose; therefore, the knitted net features represent the most suitable fabric.

Moreover, nets with the highest porosity minimize the visual impact in the field and reduce the wind loads on the supporting structures. In addition, its permeability to the air reduces the impact on environmental parameters crucial for plant growth (i.e., temperature, air humidity, transmission of the solar radiation). Consequently, among the nets tested, those with the higher mesh size $\left(\mathrm{d}_{3}=2.4 \mathrm{~mm}\right)$ would reduce the impact on the net supporting structure and on cultivation.

With regard to radiometric properties, the high transmissivity values achieved for F-d1, F-d2, and F-d3 nets were due to a combination of high porosity and transparent wires (Table 2). It is interesting to note that the $\tau$-Tot measured for F-d1, F-d2, and F-d3 nets was almost constant, while the other radiometric properties showed a variation with the porosity (Table 2). At higher porosity levels, the size of holes prevailed on the radiometric characteristics of the material the threads were made of, and a couple of values, $\tau$-Dif / $\tau$-LWIR and Haze / $\tau$-Dif, were almost coincident (Table 2) [30]. 
Preliminary results of field tests showed that the maximum height at which adult spittlebugs were trapped $(2.85 \mathrm{~m})$ was likely lower than what they can actually reach. In fact, in a previous study, Weaver and King [29], found that 60 P. spumarius adults, out of 1470 captured on tangle-foot bands placed at various heights, reached $5.90 \mathrm{~m}$ above ground. Considering the proven capability of vectors to reach considerable heights, either by flying or being transported by wind, the net should entirely cover the plants in open field nursery and olive orchards or should be designed with appropriate height to be defined in future studies. In protected cultivation, the net should be installed to shield the openings of greenhouse nurseries from the entrance of the X. fastidiosa insect vectors.

\section{Conclusions}

All tested nets avoided any intrusion of meadow spittlebug adults, and plants were successfully protected. The monofilament knitted experimental net with the widest mesh $\left(\mathrm{d}_{3}=2.4 \mathrm{~mm}, \mathrm{KW}-\mathrm{d} 3\right)$ did not show any damage or twisting and variation of the porosity. Therefore, among the tested prototypes, $\mathrm{KW}-\mathrm{d} 3$ would minimize the visual impact in the field and reduce both the wind loads on the supporting structures and the impact on environmental parameters. Laboratory tests confirmed the correlation between porosity and radiometric properties of the nets tested. The transmissivity of total $(\tau-T o t)$ and direct component of solar radiation in PAR range ( $\tau$-Dir) increased with the porosity as well as the transmissivity of the net in the IR range.

In open field nursery and olive orchards, the net should entirely cover the plant or be designed with appropriate height to be defined in future studies.

Author Contributions: Conceptualization, Methodology, Validation, Formal Analysis, Resources, Data Curation, S.C., A.D.P., G.S.G, M.L., G.S., G.S.M.; Writing-Original Draft Preparation, Writing-Review \& Editing, Supervision, S.C., A.D.P., G.S.G, G.S., G.S.M.; Project Administration, Funding Acquisition, S.C., G.S., G.S.M.

Funding: The present work was carried out under the project "Sistemi di protezione dei vivai dagli insetti vettori di Xylella (Si. Pro. Xy.net)", funded by REGIONE PUGLIA, grant number B36J16002240007.

Conflicts of Interest: The authors declare no conflict of interest. The funders had no role in the design of the study; in the collection, analyses, or interpretation of data; in the writing of the manuscript, and in the decision to publish the results.

\section{References}

1. Bucci, U.; Zambelli, M. L'Olivicoltura Pugliese. Criticità e Sviluppo. Available online: http:/ / www.confagricolturapuglia.it/area-download/category/3-documenti?download=126: 1-olivicoltura-pugliese-criticita-e-sviluppo (accessed on 22 January 2019).

2. ISTAT. Atlante dell'Agricoltura Italiana. 2013. Available online: http://www.istat.it/it/files/2014/03/Atlantedellagricoltura-italiana.-6\%C2\%B0-Censimento-generale-dellagricoltura.pdf (accessed on 22 January 2019).

3. Sardaro, R.; Fucilli, V.; Acciani, C. La stima del valore del paesaggio rurale quale strumento a supporto delle politiche di conservazione. Ital. J. Reg. Sci. 2015, 2, 125-138. [CrossRef]

4. Nigro, F.; Boscia, D.; Antelmi, I.; Ippolito, A. Fungal species associated with a severe decline of olive in Southern Italy. J. Plant Pathol. 2014, 95, 668.

5. Saponari, M.; Loconsole, G.; Cornara, D.; Yokomi, R.K.; De Stradis, A.; Boscia, D.; Bosco, D.; Martelli, G. P.; Krugner, R.; Porcelli, F. Infectivity and Transmission of Xylella fastidiosa by Philaenus spumarius (Hemiptera: Aphrophoridae) in Apulia, Italy. J. Econ. Entomol. 2014, 107, 1316-1319. [CrossRef] [PubMed]

6. Wells, J.M.; Raju, B.C.; Hung, H.Y.; Weisburg, W.G.; Mandeico-Paul, L.; Brenner, D.J. Xylella fastidiosa gen. Nov., sp. Nov.: gram-negative, xylem-limited, fastidious plant bacteria related to Xanthomonas spp. Int. J. Syst. Bacteriol. 1987, 37, 136-143. [CrossRef]

7. European Food Safety Authority. Statement of EFSA on host plants, entry and spread pathways and risk reduction options for Xylella fastidiosa Wells et al. EFSA J. 2013, 11, 3468. [CrossRef]

8. Cornara, D.; Saponari, M.; Zeilinger, A.R.; de Stradis, A.; Boscia, D.; Loconsole, G.; Bosco, D.; Martelli, G.P.; Almeida, R.P.P.; Porcelli, F. Spittlebugs as vectors of Xylella fastidiosa in olive orchards in Italy. J. Pest Sci. 2017, 90, 521-530. [CrossRef] 
9. Luvisi, A.; Nicolì, F.; De Bellis, L. Sustainable management of plant quarantine pests: the case of olive quick decline syndrome. Sustainability 2017, 9, 659. [CrossRef]

10. European Food Safety Authority. Commission Database of Host Plants Found to Be Susceptible to Xylella fastidiosa in the Union Territory-Update 9-2017. Available online: https:/ / ec.europa.eu/food/sites/food/files/plant/docs/ ph_biosec_legis_emergency_db-host-plants_update09.pdf (accessed on 22 January 2019).

11. Baù, A.; Delbianco, A.; Stancanelli, G.; Tramontini, S. Susceptibility of Olea europaea L. varieties to Xylella fastidiosa subsp. pauca ST53: systematic literature search up to 24 March 2017. EFSA J. 2017, 15, 4772. [CrossRef]

12. Möller, M.; Tanny, J.; Yan, L.; Cohen, S. Measuring and predicting evapotranspiration in an insect-proof screenhouse. Agric. For. Meteorol. 2004, 127, 35-51. [CrossRef]

13. Castellano, S.; Scarascia-Mugnozza, G.; Russo, G.; Briassoulis, D.; Mistriotis, A.; Hemming, S.; Waaijenberg, D. Plastic nets in agriculture: A general review of types and applications. Appl. Eng. Agric. 2008, 24, 799-808. [CrossRef]

14. Yang, G.; Guo, Z.; Ji, H.; Sheng, J.; Chen, L.; Zhao, Y. Application of insect-proof nets in pesticide-free rice creates an altered microclimate and differential agronomic performance. PeerJ 2018, 6, e6135. [CrossRef] [PubMed]

15. Berlinger, M. J.; Taylor, R.A.; Lebiush Mordechi, S.; Shalhevet, S.; Spharim, I. Efficiency of insect exclusion screens for preventing whitefly transmission of tomato yellow leaf curl virus of tomatoes in Israel. Bull. Entomol. Res. 2002, 92, 367-373. [CrossRef] [PubMed]

16. Fatnassi, H.; Boulard, T.; Bouirden, L. Simulation of climatic conditions in full-scale greenhouse fitted with insect-proof screens. Agric. For. Meteorol. 2003, 118, 97-111. [CrossRef]

17. Rigakis, N.; Katsoulas, N.; Teitel, M.; Bartzanas, T.; Kittas, C. A simple model for ventilation rate determination in screenhouses. Energ. Build. 2015, 87, 293-301. [CrossRef]

18. Mahmood, A.; Hu, Y.; Tanny, J.; Asante, E. A. Effects of shading and insect-proof screens on crop microclimate and production: a review of recent advances. Sci. Hortic. 2018, 41, 241-251. [CrossRef]

19. Gogo, E.O.; Saidi, M.; Itulya, F.M.; Martin, T.; Baird, V.; Ngouajio, M. Microclimate modification and insect pest exclusion using agronets improves pod yield and quality of French beans. HortScience 2014, 49, 1-7. [CrossRef]

20. Martin, T.; Assogba-Komlan, F.; Houndete, T.; Hougard, J.M.; Chandre, F. Efficacy of mosquito netting for sustainable small holders' cabbage production. Africa. J. Econ. Entomol. 2006, 99, 450-454. [CrossRef] [PubMed]

21. Lewis, T. The horizontal and vertical distribution of flying insects near artificial windbreaks. Ann. Appl. Biol. 1967, 60, 23-31. [CrossRef]

22. Tremblay, E. Entomologia Applicate, 3rd ed.; Liguori Editore: Napoli, Italy, 1995; Volume 2, p. 408. ISBN 8820710250.

23. Janse, J.D.; Obradovic, A. Xylella fastidiosa: its biology, diagnosis, control and risks. J. Plant Pathol. 2010, 92, 35-48.

24. Germain, J.F. Fact Sheet Philaenus spumarius. ANSES-LSV Unité D’Entomologie et Plantes Invasives. Available online: https://www.ponteproject.eu/wp-content/uploads/2017/01/Philaenus-spumarius (accessed on 22 January 2019).

25. Castellano, S.; Hemming, S.; Russo, G.; Mohammadkhani, V.; Swinkel, G.L.A.M.; Scarascia-Mugnozza, G. Radiometric properties of agricultural permeable coverings. J. Agric. Eng. 2010, 41, 1-12. [CrossRef]

26. Hemming, S.; Swinkel, G.L.A.M.; Castellano, S.; Russo, G.; Scarascia-Mugnozza, G. Numerical model to estimate the radiometric performance of net covered structures. In Proceedings of the AgEng Congress, Hersonissos, Greece, 23-25 June 2008.

27. Castellano, S.; Starace, G.; De Pascalis, L.; Lippolis, M.; Scarascia Mugnozza, G. Test results and empirical correlations to account for air permeability of agricultural nets. Biosyst. Eng. 2016, 150, 131-141. [CrossRef]

28. Tridan, S.; Valič •, N.; Žežlina, I.; Bergant, K.; Žnidarčič, D. Light blue sticky boards for mass trapping of onion thrips, Thrips tabaci Lindeman (Thysanoptera: Thripidae), in onion crops: Factor fantasy? J. Plant. Dis. Protect. 2005, 112, 173-180.

29. Weaver, C.R.; King, D.R. Meadow spittlebug, Philaenus leucophthalmus (L.). Ohio Agric. Exp. Stat. Bull. 1954, 741,1-99.

30. Castellano, S.; Candura, A.; Scarascia Mugnozza, G. Relationship between solidity ratio, colour and shading effect of agricultural nets. Acta Hortic. 2008, 801, 253-258. [CrossRef]

(C) 2019 by the authors. Licensee MDPI, Basel, Switzerland. This article is an open access article distributed under the terms and conditions of the Creative Commons Attribution (CC BY) license (http:/ / creativecommons.org/licenses/by/4.0/). 